\title{
Uji Kualitas Fisik Susu Sapi Friesh Holland (Studi Kasus Peternakan Claretian Novisiat Benlutu Kabupaten TTS)
}

\section{Maria M. Tefa ${ }^{\mathrm{a}}$, Stefanus Sio $^{\mathrm{b}}$ dan Theresia Ika Purwantiningsih ${ }^{\mathrm{c}}$}

${ }^{a}$ Fakultas Pertanian, Universitas Timor, Kefamenanu, TTU - NTT, Indonesia, email: tefamaria273@gmail.com

${ }^{b}$ Fakultas Pertanian, Universitas Timor, Kefamenanu, TTU - NTT, Indonesia, email: stefsio67@ gmail.com

cFakultas Pertanian, Universitas Timor, Kefamenanu, TTU - NTT, Indonesia, email: theresiaicha@ gmail.com

\section{Article Info}

Article history:

Received 12 Juni 2019

Received in revised form 19 Juni 2019

Accepted 14 Juli 2019

DOI:

https://doi.org/10.32938/ja.v4i3.737

Keywords:

Kualitas fisik susu

Uji alkohol

Uji berat jenis

Uji didih

$\mathrm{Uji} \mathrm{pH}$

\section{Abstrak}

Penelitian ini bertujuan untuk mengetahui kualitas susu yang ada di Peternakan Claretian Novisiat Benlutu, ditinjau dari uji alkohol, uj didih, uji berat jenis dan derajat keasaman. Penelitian ini menggunakan sampel susu segar yang diambil di Benlutu. Data uji alkohol, uji didih uji berat jenis dan derajat keasaman dianalisis menggunakan analisis deskriptif. Data yang diperoleh dianalisis menggunakan analisis deskriptif dan disajikan dalam bentuk tabel dan pembahasan dilakukan secara deskriptif berdasarkan hitungan rata-rata dan dan standar deviasi selanjutnya dibandingkan dengan SNI 3141.1.2011 tentang mutu susu segar. Hasil penelitian menunjukkan negatif pada uji alkohol dan uji didih, hal ini sesuai dengan SNI 2011 tentang susu segar. Sedangkan pada uji derajat keasaman susu menunjukkan angka 6,8 sesuai juga dengan SNI 2011 tentang derajat keasaman susu yang berkisar antara 6,0-7,5, pada uji berat jenis menunjukkan skala 1,0276, hal ini sudah memenuhi SNI. Berdasarkan hasil penelitian maka dapat disimpulkan bahwa susu segar yang diperoleh dari Peternakan Claretian Novisiat Benlutu secara fisik berkualitas baik dan layak dikonsumsi, dibuktikan dengan uji kualitas pada susu segar memenuhi SNI ditinjau dari uji alkohol, titrasi keasaman, dan uji didih, dan uji berat jenis.

\section{Pendahuluan}

Susu adalah makanan yang istimewa bagi manusia karena kelezatan dan komposisinya yang ideal. Selain susu mengandung semua zat yang dibutuhkan oleh tubuh, semua zat makanan yang terkandung di dalam susu dapat diserap oleh darah dan dimanfaatkan oleh tubuh. Sebagai bahan makanan yang bernilai gizi tinggi, susu menjadi salah satu pilihan utama masyarakat untuk menjaga kesehatannya.

Permintaan masyarakat terhadap susu dan hasil olahannya untuk memenuhi kebutuhan gizi semakin meningkat, membuat pihak-pihak terkai berusaha untuk meningkatkan produksi susu tanpa menyampingkan kualitas kesegaran susu. Peternak berusaha terus meningkatkan dan menjaga kualitas dan kesegaran susu agar dapat diterima di Industri Pengolahan Susu (IPS) dan dikonsumsi oleh masyarakat. Kualitas susu yang rendah dapat berpengaruh terhadap harga susu yang diterima oleh peternak. Semakin baik kualitas susu yang dihasilkan, harga yang diberikan kepada peternakan akan semakin baik. Sebaliknya kualitas susu yang jelek akan berimbas kepada penolakan susu. Selain itu kualitas susu yang rendah berpengaruh terhadap hasil olahan susu yang akan dihasilkan.

Peternakan sapi perah yang dimiliki oleh Claretian Novisiat Benlutu merupakan salah satu peternakan sapi perah yang berada di NTT khususnya Pulau Timor. Peternakan ini masih menerapkan sistem pemeliharaan yang sangat sederhana sehingga belum menjamin ketersediaan susu yang berkualitas hal ini mempengaruhi produksi susu yang relatif masih terbatas karena belum didukung teknologi yang optimal dan rendahnya perhatian masyarakat untuk mengkonsumsi susu segar. Peran pemerintah daerah diharapkan dalam pengembangan sapi perah disertai pendampingan dari tenaga ahli.

\section{Metode}

Penelitian ini di laksanakan Laboratorium Fakultas Pertanian Universitas Timor selama \pm 1 minggu terhitung dari bulan januari sampai selesai. Alat yang digunakan dalam pengujian berat jeni adalah laktodensimeter, gelas ukur dan thermometer. Alat yang digunakan dalam pengujian alkohol adalah tabung reaksi, pipet ukur dan gelas ukur. Alat yang digunakan dalam pengujian keasaman adalah mikroburet pipet ukur $1 \mathrm{ml}$, elenmeyer dan pengaduk kaca. Alat yang digunakan dalam pengujian didih adalah tabung reaksi, penjepit dan bunsen. Alat yang digunakan dalam pengujian $\mathrm{pH}$ adalah $\mathrm{pH}$ meter.

Bahan yang digunakan dalam Penelitian ini adalah susu sapi $\mathrm{FH}$ sebanyak 5 liter, aquades, larutan $\mathrm{NaOH}$, indikator PP dan alkohol $70 \%$ Variabel yang diteliti adalah uji berat jenis, uji alkohol, uji keasaman, uji didih dan uji $\mathrm{pH}$. Data yang diperoleh dianalisis menggunakan analisis deskriptif yaitu di mana data yang diperoleh disajikan dalam bentuk tabel dan pembahasan dilakukan secara deskriptif berdasarkan hitungan rata-rata dan dan standar deviasi (Steel dan torrie, 1995) selanjutnya dibandingkan dengan SNI 3141.1.2011 tentang mutu susu segar.

\section{Hasil dan Pembahasan}

\subsection{Berat Jenis Susu}

Berat jenis suatu bahan adalah perbandingan antara berat bahan tersebut dengan berat air pada volume dan temperatur yang sama. Berat jenis susu dipengaruhi oleh kadar lemak (KL) dan bahan kering tanpa lemak (BKTL). Semakin tinggi nilai kadar lemak dalam susu maka berat jenis susu akan semakin rendah. Nilai berat jenis susu akan semakin tinggi apabila kadar BKTL di dalam susu juga semakin tinggi (Muctadi et al., 2010). Hasil uji berat jenis susu yang diambil di Peternakan Novisiat Claretian Benlutu dapat dilihat pada Tabel 1.

Hasil penelitian menunjukkan bahwa rata-rata nilai berat jenis sampe susu segar lebih tinggi dibandingkan standar minimum yang telah ditetapkan pada SNI NO. 01-3141-2011. Rata-rata nilai berat jenis susu yang diperoleh dari analisis data menunjukkan 1.0276, sedangkan standar minimum berat jenis susu segar yang ditetapkan dalam SNI adalah 1.0270. Menurut Nugroho et al. (2011), susu segar dari ternak sapi di Indonesia rata-rata memiliki nilai berat

Tabel 1. Hasil uji berat jenis susu yang diambil di Peternakan Novisiat Claretian Benlutu.

\begin{tabular}{cc}
\hline Sampel susu & Berat jenis susu \\
\hline S1 & 1,0275 \\
S2 & 1,0275 \\
S3 & 1,0280 \\
Rata-rata & 1,0276 \\
Std. Deviasi &, 0002887 \\
\hline
\end{tabular}

jenis sebesar 1.0250. Nilai tersebut tidak jauh berbeda dengan nilai rata-rata berat jenis susu segar yang diperoleh dari penelitian ini. Berat jenis susu dapat dipengaruhi oleh pakan. Suherman (2005) menyatakan bahwa pemberian pakan yang baik pada sapi perah yaitu dengan imbangan rumput lapangan dan konsentrat sebesar 70:30. Selain itu, berat jenis susu juga dipengaruhi oleh kandungan bahan kering pakan sehingga kenaikan bahan kering akan meningkatkan berat jenis susu. Menurut Zurriyati et al. (2011), berat jenis susu dipengaruhi oleh kadar lemak dan bahan kering tanpa lemak dalam susu juga meningkat, sedangkan penurunan berat jenis susu terjadi apabila kadar lemak dalam susu meningkat. Nilai berat jenis susu akan semakin tinggi apabila kadar BKTL di dalam susu semakin banyak. Hasil penelitian Utami et al. (2014) menunjukkan bahwa konsentrat sangat berpengaruh terhadap berat jenis susu. Pemberian konsentrat kurang dari 30\% akan menurunkan berat jenis susu. Penurunan berat jenis susu dapat disebabkan adanya mastitis subklinis. Selanjutnya menurut Visweshar dan Krishnaiah (2005), penurunan nilai berat jenis susu dapat disebabkan oleh penambahan air, penambahan lemak, dan kenaikan suhu. Penambahan air dapat menyebabkan susu menjadi cair sehingga konsentrasi zat-zat penyusunan dalam susu menurun. Penurunan konsentras zat-zat penyusunan dalam susu dapat menurunkan nilai berat jenis susu. Penambahan lemak dapat menurunkan berat jenis susu karena nilai berat jenis lemak yang rendah. Nilai berat jenis suatu koloid merupakan penjumlahan dari nilai berat jenis masing-masing penyusunnya, sehingga bila konsentrasi lemak tinggi dalam susu maka lemak dengan berat jenisnya yang rendah akan mempengaruhi nilai berat jenis koloid.

\section{2 pH Susu}

Pengukuran $\mathrm{pH}$ susu bertujuan untuk mengetahui $\mathrm{pH}$ susu segar. Susu segar mempunyai sifat ampoter (dapat bersifat asam dan basa) (Saleh, 2004). Sebagian besar asam yang ada dalam susu adalah asam laktat. Keasaman dalam susu dapat disebabkan oleh senyawa-senyawa yang bersifat asam seperti senyawa fosfat komplek, asam sitrat, asam-asam amino, dan karbondioksida yang larut dalam susu. Bila nilai $\mathrm{pH}$ Susu lebih rendah dari 6,6 maka susu segar tersebut mengalami kerusakan karena adanya aktivitas bakteri yang memfermentasi susu sehingga rasanya menjadi asam (Buckle et al., 2010).

Faktor yang mempengaruhi jumlah bakteri dan $\mathrm{pH}$ dalam susu antara lain lingkungan tempat pemerahan, sanitasi kandang dan peralatan, lama pemerahan, dan penyakit yang disebabkan oleh bakteri susu maupun obatobatan (Pramesthi et al., 2015). Pada pengukuran $\mathrm{pH}$ diperoleh hasil pada Tabel

Dari hasil penelitian menunjukkan bahwa rata-rata $\mathrm{pH}$ pada susu segar menunjukkan hasil 6,8. Hal ini sudah memenuhi standar kualitas susu yang ditetapkan oleh (SNI 2011) yaitu antara 6,3- 6,8. Susu yang berasal dari Peternakan Sapi Perah Novisiat Claretian Benlutu dalam kondisi yang baik Menurut Buckle et al. (2010) aktivitas bakteri dalam susu akan menurunkan $\mathrm{pH}$ secara nyata. 
Tabel 2. Hasil Uji pH Susu yang diambil di Peternakan Novisiat Claretian Benlutu

\begin{tabular}{cc}
\hline Sampel susu & pH susu \\
\hline S1 & 6,7 \\
S2 & 6,9 \\
S3 & 6,9 \\
Rata-rata & 6,8300 \\
Std. Deviasi & 1155 \\
\hline
\end{tabular}

Menurunnya $\mathrm{pH}$ susu menyebabkan protein seperti kasein berada pada titik isoelektriknya sehingga protein tersebut akan menggumpal. Kenaikan $\mathrm{pH}$ susu juga dapat menjadi tanda adanya mastitis pada sapi. Mirdhayati et al. (2008) menyatakan bahwa terjadinya kenaikan dan penurunan $\mathrm{pH}$ susu disebabkan oleh hasil konversi dari laktosa menjadi asam laktat oleh mikroorganisme dan aktivitas enzimatik.

\subsection{Derajat Keasaman}

Derajat asam susu menunjukkan dua hal yaitu keasaman yang memang ada dalam susu dan keasaman yang di sebabkan oleh susu yang terkontaminasi bakteri, bakteri merubah laktosa menjadi asam laktat. Indikator phenopthalaein (PP) tidak berwarna pada suasana asam dan akan merubah merah pada suasana basa. Pemeriksaan derajat keasaman susu dapat dilihat pada Tabel 3.

Tabel 3. Pengujian Derajat keasaman susu di Novisiat Claretian Benlutu

\begin{tabular}{cc}
\hline Sampel susu & Derajat Keasaman \\
\hline S1 & 7,2 \\
S2 & 6,4 \\
S3 & 6,8 \\
Rata-rata & 6,8000 \\
Std. Deviasi &, 40000 \\
\hline
\end{tabular}

Dari hasil penelitian menunjukkan bahwa susu sapi di Novisiat Claretian Benlutu memenuhi persyaratan dan layak dikonsumsi. Hal ini sesuai SNI NO 01-3141:1-2011 yang menyatakan bahwa standar derajat keasaman susu segar adalah 6,0-7,5. Hasil ini menunjukkan bahwa susu sapi di Benlutu memenuhi persyaratan di Indonesia. Hal yang menyebabkan susu masih dalam keadaan utuh, sehingga tidak terjadi proses penguraian laktosa menjadi asam laktat oleh hasil fermentasi bakteri dan tidak terjadi peningkatan derajat keasaman susu. Prinsip pada uji derajat asam yaitu secara titrasi ditetapkan kadar asam yang terbentuk dalam susu. Susu dalam ambing sapi sehat dapat mengandung 500 bakteri/ml susu dalam jumlah ini akan meningkat apabila sapi dalam keadaan sakit. Dari jumlah ini terdapat bakteri-bakteri pembentuk asam laktat seperti Lactobacillus dan Lactobasillus thermophilus (Umar dan Novita. 2014). Bakteri-bakteri tersebut termasuk dalam golongan bakteri asam laktat yang secara normal berada dalam susu.

\subsection{Uji Alkohol}

Uji alkohol dilakukan untuk mengetahui adanya susu yang rusak, apabila terdapat butir-butir susu pada dinding tabung menunjukkan susu tersebut positif telah rusak. Susu segar yang berkualitas baik tidak akan pecah atau menggumpal bila dipanaskan atau dididihkan. Sebaliknya, susu yang bermutu jelek akan mengalami penggumpalan bila di panaskan. Hal ini terjadi karena adanya asam yang dihasilkan oleh mikroba dari peruraian laktosa. Asam tersebut mengakibatkan protein susu mudah mengalami denaturasi dan penggumpalan bila dilakukan pemanasan (Soriah, 2010). Hasil uji alkohol pada susu segar di Peternakan Novosiat Claretian Benlutu dapat dilihat pada Tabel 4.

Tabel 4. Hasil uji Alkohol pada susu segar di Peternakan Novisiat Claretian Benlutu.

\begin{tabular}{cc}
\hline Sampel susu & Alkohol \\
\hline S1 & $(-)$ Negatif \\
S2 & $(-)$ Negatif \\
S3 & $(-)$ Negatif \\
\hline
\end{tabular}

Berdasarkan hasil pengujian sampel susu selama penelitian menunjukkan bahwa tanda negatif atau tidak gumpalan terlihat pada dinding tabung reaksi, maka susu masih dalam keadaan baik. Hasil pengujian tersebut sesuai dengan SNI (2011) bahwa susu segar dengan kualitas baik ketika dilakukan pengujian alkohol 70\% menunjukkan tanda negatif. Pada uji alkohol susu yang tidak baik (misalnya susu asam) akan pecah atau menggumpal jika ditambahkan alkohol $70 \%$ dan sebaliknya jika tidak menggumpal maka susu tersebut baik dan layak dikonsumsi. Alkohol memiliki daya dehidrasi yang menarik gugus $\mathrm{H}+$ Dari ikatan mantel air, protein, sehingga protein dapat melekat satu dengan yang lain akibatnya kestabilan protein berkurang yang dinamakan susu pecah (Sudarwanto, 2005). Pecahnya susu disebabkan oleh berkembangbiaknya bakteri asam susu, dalam hal ini laktosa diubah menjadi asam laktat. Semakin tinggi derajat keasaman susu, semakin berkurang jumlah alkohol dengan kepekatan yang sama dibutuhkan untuk memecahkan susu yang sama banyaknya (Suardana dan Swacita, 2004).

\subsection{Uji Didih}

Uji didih merupakan uji kualitas susu dengan cara mendidihkan. Uji ini bernilai positif jika terdapat butir-butir protein karena $\mathrm{pH}$ tinggi. Sudarwanto (2005) menyatakan bahwa berapa jenis bakteri dapat melakukan fermentasi pada susu dan merubah laktosa menjadi asam laktat sehingga susu tersebut mengalami penggumpalan. Uji didih di peternakan Novisiat Claretian Benlutu dapat dilihat pada Tabel 5 .

Tabel 5. Hasil uji didih susu segar pada Peternakan Novisiat Claretian Benlutu

\begin{tabular}{cc}
\hline Sampel susu & Didih \\
\hline S1 & $(-)$ Negatif \\
S2 & $(-)$ Negatif \\
S3 & $(-)$ Negatif \\
\hline
\end{tabular}

Berdasarkan hasil pengujian sampel susu selama penelitian menunjukkan bahwa tidak terdapat gumpalan yang terdapat pada dinding tabung reaksi maka susu masih dalam keadaan baik. Hal ini sesuai SNI (2011) bahwa susu segar dengan kualitas baik ketika dilakukan pengujian dan menunjukkan tanda negatif (-). Hal ini juga sesuai dengan pendapat Nababan et al. (2014), yang melakukan pengujian terhadap kualitas susu segar di kota Denpasar pada tingkat produsen. Pengujian dikatakan positif, ditandai adanya gumpalan yang menempel di dinding tabung reaksi, yaitu partikel-partikel kasar yang melekat pada dinding tabung (Suardana dan Swacita 2009).

Susu yang tidak baik (susu asam) akan pecah atau menggumpal bila dimasak sampai mendidih karena kestabilan kaseinnya berkurang. Koagulasi kasein umumnya menyebabkan pecahnya susu. Koagulasi larutan tersebut disebabkan oleh keasaman dan suhu tinggi. Susu yang pecah saat dididihkan dapat disebabkan oleh derajat keasaman susu yang tinggi, susu tercampur kolostrum dan keadaan fisiologi individu sapi menyimpang sehingga menyebabkan komposisi susu tidak stabil.

\section{Simpulan}

Dari hasil penelitian dapat disimpulkan bahwa susu segar yang diperoleh dari Peternakan Claretian Novisiat Benlutu secara fisik berkualitas baik dan layak dikonsumsi, dibuktikan dengan uji kualitas pada susu segar memenuhi SNI ditinjau dari uji alkohol, titrasi keasaman, dan uji didih, dan uji berat jenis.

Pustaka

Buckle, K. A., R. A Edwards, G. H Fleet, dan M. Wooton. 2010. Ilmu Pangan. U.I Press. Jakarta (Diterjemahkan : H Purnomo dan Adiono).

Mirdhayati, I., J. Handoko dan K.U. Putra. 2008 Mutu Susu Segar di UPT Ruminansia Besar. Dinas Peternakan Kabupaten Kampar Propinsi Riau. Fakultas Pertanian dan Peternakan Universitas Islam Negeri Sultan Syarif Kasim. Jurnal Peternakan, 5 (1) : 14-21.

Muctadi T.R., Sugiyono., Ayustaningwarno, F. 2010. Ilmu Pengetahuan Bahan Pangan. Bandung (ID) : Alfabeta.

Nababan, L. A., I Ketut, S dan Ida, B. N. S 2014. Ketahanan susu segar pada penyimpanan suhu ruang ditinjau dari uji tingkat keasaman, Didih, dan Waktu Reduktase. Indonesia Medicus Veteriner, 3 (4) : 274-282.

Nugroho, S.W.P, Pudjotomo, D dan Tifani, K.T. 2011.Analisa penyebab penurunan daya saing produk susu sapi dalam negeri terhadap susu sapi impor pada industri pengolahan susu (IPS) dengan metode fault tree analysis (FTA) dan barrier analysis. J@TI Undip : Jurnal teknik Industri, 6 (2): :71-80.

Pramesthi R, Suprayogi TH, Sudjamogo.2015. Total bakeri dan pH susu segar sapi FH. Total bakteri dan $\mathrm{pH}$ susu segar sapi perah friesien holstein di Unit Pelaksana Teknis Daerah Pembibitan Ternak Unggul Mulyorejo Tengarang-Semarang. Anim Aric J, 4 (1): 69-74

Saleh, E. 2004.Dasar Pengolahan susu dan Hasil Ikutan Ternak. Program Studi Produksi ternak. Fakultas Pertanian Universitas Sumatera Utara.

Soriah, W. 2010. Hubungan variasi pakan terhadap mutu susu segar di desa pasirbuncir kecamatan caringin kabupaten bogor. Jurnal Penyuluhan Pertanian, 5 ( 1) : 67-77.

Standar Nasional Indonesia. 2011. SNI 3141,1:2011. Susu Segar. Badan standarisasi Nasional, Jakarta.

Steel dan Torrie 1995 Prinsip dan Prosedur Statistik Suatu Pendekatan Biometrik Sumantrik B, Penerjemah Gramedia Jakarta.

Suadarna, I.W. dan IBN, Swacita. 2004. Food Hygenic. Petunjuk Laboratorium. Fakultas Kedokteran Hewan. Universitas Udayana Denpasar.

Suadarna, I.W. dan IBN, Swacita. 2009. Hygenic Makanan. Kajian Teori dan Prinsip Dasar. Fakultas Kedokteran Hewan. Universitas Udayana Denpasar.

Sudarwanto, M. 2005. Bahan kuliah hygiene makanan. Bagian penyakit hewan dan kesehatan masyarakat veteriner FKH IPB. Bogor

Suherman, D. 2005. Imbangan rumput lapangan dan konsentrat dalam ransum terhadap kualitas produksi susu sapi perah holstein. Animal production, $7(1): 14-20$ 
Umar, R dan Novita, A. 2014.Derajat Keasaman dan angka reduktase susu sapi pasteurisasi dengan lama penyimpanan yang berbeda. J. Veteriner, 8 (1) : 43-46.

Utami, K.B, Radiati, L.E dan Sudawardojo, P. 2014. Kajian Kualitas susu sapi perah PFH (studi kasus pada anggota koperasi Agro Niaga di Kecamatan Jabung Kabupaten Malang). J. Ilmu-ilmu Peternakan, 24 (2) : 58-66.

Visweshar, S.K dan Krishnaiah, N 2005. Quality control of milk and processing. Di dalam : Reddy PS, editor. Intermediate Vocational course, Andrha Pradesh, 2005. Andrha Pradesh (IN) :Telugu Academy Publication. Hlm 14-25

Zurriyati, Y., Noor, R.R. dan Maheswari, R.R.A. 2011 Analisis molekuler genotipe kappa Kasein (K-Kasein) dan komposisi susu kambing peranakan etawa, saanen, dan persilangannya. JITV, 16 (1) : 61-70. 